Gut, 1986, 27, 581-586

Case report

\title{
Effect of two new antisecretory drugs on fluid and electrolyte transport in a patient with secretory diarrhoea
}

\author{
CHRISTINE EDWARDS, P A CANN, N W READ, AND C D HOLDSWORTH \\ From the Clinical Research Unit, Royal Hallamshire Hospital, Sheffield
}

SUMmaRY The effect of oral lidamidine hydrochloride and subcutaneous long acting somatostatin analogue, SMS 201-995, on stool output and salt and water transport in the small intestine was investigated in a patient with gross secretory diarrhoea caused by a vasoactive intestinal polypeptide (VIP) secreting tumour in the liver. Transport in the jejunum and ileum were assessed by steady state perfusion techniques. Under basal conditions, the patient was absorbing fluid and electrolytes from the jejunum and ileum, but at rates that were abnormally low. Lidamidine had no effect on either intestinal transport or stool frequency and output. SMS 201-995 increased intestinal absorption in the jejunum and ileum, reduced plasma VIP concentrations, daily stool frequency and weight, and enabled the patient to resume a normal diet without oral or intravenous fluid and electrolyte supplements. After two months of treatment, medical control was becoming increasingly difficult and stool output had risen again to 2 litres per day. Surgical resection, fortunately, was possible and led to resolution of symptoms and normal plasma VIP concentrations.

Patients who have VIP secreting tumours present with copious diarrhoea caused by massive small intestinal secretion. The diarrhoea is often resistant to treatment with conventional antidiarrhoeal agents, though drugs which inhibit intestinal secretion offer the possibility of effective symptomatic treatment. We have investigated the action of two new antisecretory agents; lidamidine $\mathrm{HCl}$ (Rorer), an alpha $_{2}$ adrenoreceptor agonist and SMS 201-995 (Sandoz), a long acting analogue of somatostatin, on intestinal fluid and electrolyte transport and faecal output in a patient with severe diarrhoea caused by an hepatic tumour secreting VIP.

\section{Case report}

The patient was a 44 year old man, who had been quite well until early 1980 when he developed a duodenal ulcer, which initially responded to a course of ranitidine (Zantac, Glaxo), but recurred

Address for correspondence: Dr C D Holdsworth, Clinical Research Unit, H Floor, Royal Hallamshire Hospital, Sheffield S10 2JF.

Received for publication 12 September 1985. whenever treatment was stopped. The ulcer symptoms were eventually relieved by truncal vagotomy with pyloroplasty, done in February 1983. Diarrhoea started a few days after the operation, and gradually became worse until, by November 1983 , he had lost $6.3 \mathrm{~kg}$ in weight, was hypokalaemic and was admitted to hospital passing between 1500 and $3000 \mathrm{~g}$ faeces containing between $40-100 \mathrm{mmol}$ (mEq) sodium and 70-200 $\mathrm{mmol}(\mathrm{mEq})$ potassium per day. Faecal fluid and electrolyte losses continued at the same rapid rate when the patient took nil by mouth for $\mathbf{4 8}$ hours, all fluid and electrolyte requirements being given intravenously (Figure). Plasma concentrations of gastrin, pancreatic polypeptide, neurotensin and glucagon were normal but plasma VIP was grossly raised at $323 \mathrm{pmol} / 1$ (normal range $<30 \mathrm{pmol} / \mathrm{l}$ ). Small bowel enema examination was normal apart from marked dilution of barium and very rapid transit. The fluid, electrolyte and weight losses were eventually corrected with a combination of a constant fluid diet (Fortison Standard, Cow \& Gate Ltd, 21/day), glucose/electrolyte replacement drink (10 sachets of Dioralyte per day; Armour Pharmaceutical Co. Ltd, Eastbourne) plus inter- 


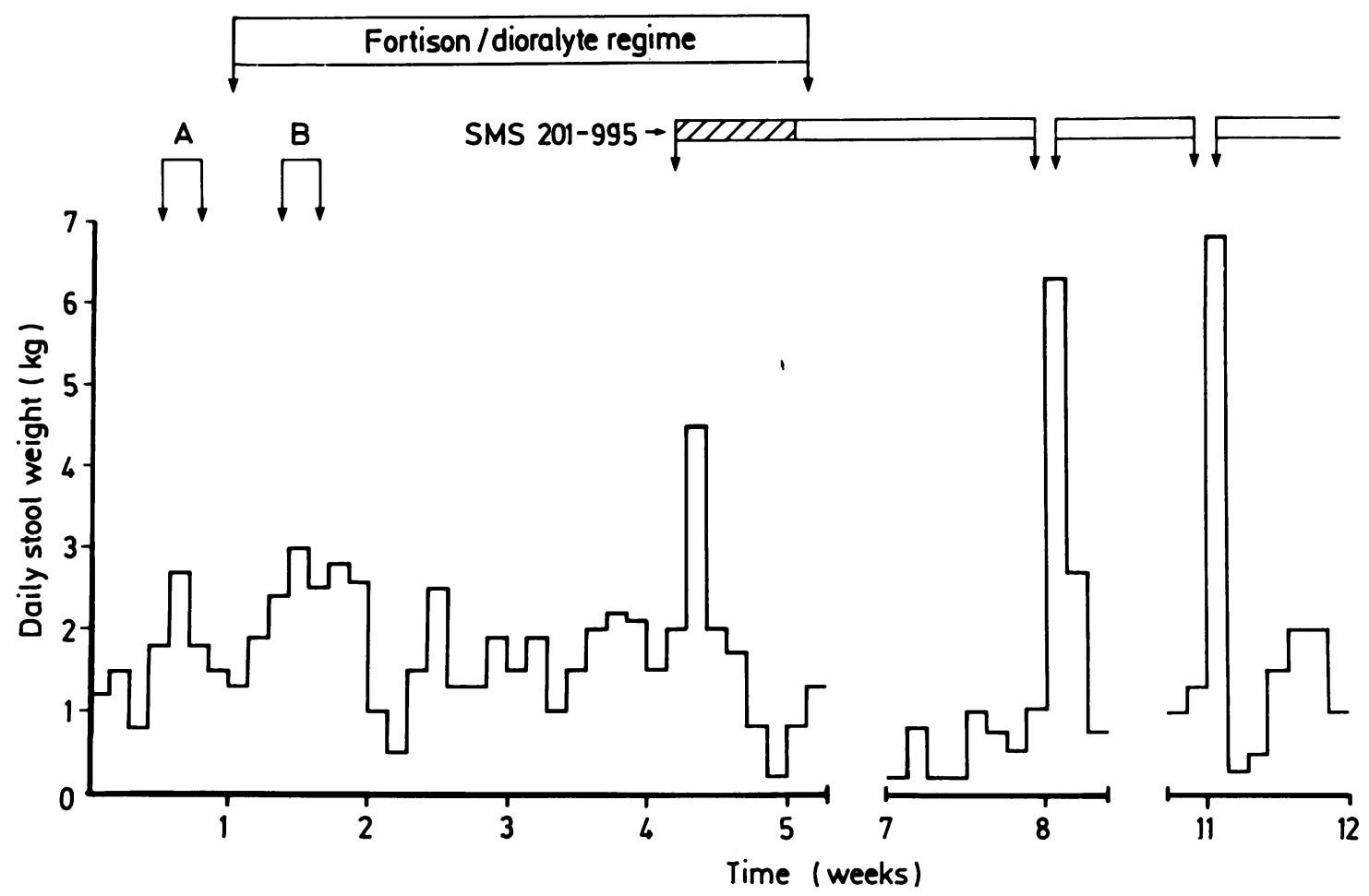

Figure Daily stool weight of patient with a VIPoma: response to treatment with intravenous fluids, lidamidine and SMS 201-995. A: Intravenous fluids, nil orally, B: Oral lidamidine. Hatched bar indicates when SMS 201-995 was administered $B I D$; unhatched bar indicates administration TID. The breaks in the time axis indicate when patient was allowed to spend time at home.

mittent intravenous isotonic saline with potassium. This regime provided a maximum overall daily intake of 6 litres of fluid, $2000 \mathrm{Kcal}, 80 \mathrm{~g}$ protein, $260 \mathrm{mmol}$ potassium and $570 \mathrm{mmol}$ sodium. The patient remained reasonably well for the 30 days indicated in the Figure.

Ultrasound examination, selective coeliac axis angiography and an abdominal CAT-scan showed a large tumour in the right lobe of the liver, close to the porta hepatis, but no lesion in the pancreas. Selective venous blood samples from a catheter introduced via the femoral vein confirmed that the hepatic lesion was the probable source of the excess VIP. (Inferior vena cava: $353 \mathrm{pmol} / \mathrm{l}$, superior vena cava: 339 , middle lobe liver: 767 , upper right lobe liver; 544, tumour site: 678; normal range $<30$ $\mathrm{pmol} / \mathrm{l})$.

During this admission the patient received oral treatment with lidamidine, in five doses of $4 \mathrm{mg}$ given at six hourly intervals, followed by three doses of $8 \mathrm{mg}$ at the same intervals (Figure). Stool output was not reduced during treatment with lidamidine (Figure).
Four weeks after admission, the somatostatin analogue (SMS 201-995, Sandoz Ltd, Feltham, Middlesex) was started at a dose of $50 \mu \mathrm{g}$ twice daily subcutaneously, increasing to $50 \mu \mathrm{g}$ thrice daily after one week. This treatment produced an immediate marked improvement in stool output and frequency making it possible for the patient to dispense with both the oral supplementary electrolytes and any additional intravenous replacement and to return to a normal diet one week later (Figure). Upon two separate occasions, the somatostatin analogue was withheld for 24 hours and the stool output increased to more than 6 litres/day (Figure) on each occasion and the patient became drowsy and hypotensive with marked facial flushing. He recovered within three hours of a somatostatin analogue injection. A similar rebound effect has been reported in another similar patient when somatostatin treatment was stopped. 1

After two months on the somatostatin analogue, his general condition remained good but the stool output had gradually increased to $2000 \mathrm{~g} /$ day (Figure). The patient was referred to the Hammer- 
smith Hospital, London, where the hepatic tumour was removed by quadrate lobectomy and no other lesion was found. This plasma VIP concentration fell to the normal range after the operation and has remained at that level. The patient has since been free of symptoms, with a normal bowel habit and on no treatment.

\section{Methods}

INTESTINAL PERFUSION STUDIES

Perfusion

The transport of fluid and electrolytes in the jejunum and ileum was measured by steady state segmental perfusion techniques. On the day before each study, the patient swallowed a radio-opaque flexible polyvinyl probe (od $=5 \mathrm{~mm}$ ) consisting of three tubes bonded together and terminating in a rubber bag containing $1.2 \mathrm{ml}$ mercury. One tube was used to infuse solutions into the small intestine. The other two tubes ended in aspiration ports $10 \mathrm{~cm}$ and $35 \mathrm{~cm}$ distal to the infusion port. The probe was positioned in the small intestine with the aid of fluoroscopy so that the infusion port was $90 \mathrm{~cm}$ from the teeth.

After an overnight fast, the patient lay on a couch while an isotonic electrolyte solution containing $105 \mathrm{mmol} \mathrm{NaCl}, 30 \mathrm{mmol} \mathrm{NaHCO}, 5 \mathrm{mmol} \mathrm{KCl}$ and $5 \mathrm{~g} / \mathrm{l}$ polyetheylene glycol (PEG) 4000 was infused at a steady rate of $10 \mathrm{ml} / \mathrm{min}$ into the intestine. After a 40 minute equilibration period, samples were aspirated from each aspiration port at a rate of $1.5 \mathrm{ml} / \mathrm{min}$ for one hour (test period). Sampling from proximal and distal ports were staggered by 10 minutes to allow for the normal transit time of fluid down the $25 \mathrm{~cm}$ test segment, though this delay may have been inappropriate in a patient with secretory diarrhoea, whose endogenous flow rate is high. It is unlikely, however, that any discrepancy in predicted and actual segmental transit times would have a significant influence on fluid transport over a one hour period.

\section{Effect of lidamidine}

Intestinal fluid and electrolyte transport was measured in the jejunum ( $90 \mathrm{~cm}$ from the teeth) for one hour test periods before and after a $10 \mathrm{mg}$ oral dose of lidamidine. Thirty minutes was allowed between administration of the drug and the start of the second equilibration period. Blood pressure and pulse rate were monitored throughout the study. The patient was on no other treatment when this perfusion study was done.

\section{Effect of the somatostatin analogue}

The perfusion studies were carried out on two consecutive days. Intestinal fluid and electrolyte transport was measured in the jejunum on the first day, then the probe was allowed to progress down the small intestine until the infusion port was $210 \mathrm{~cm}$ from the teeth and the ileal perfusion was carried out on the second day. On each day the morning dose of SMS 201-995 was omitted and hydration was maintained intravenously. A plasma-like solution was infused into the intestine for an initial 40 minute equilibration period, and a 60 minute test period. A subcutaneous injection of $50 \mu \mathrm{g}$ somatostatin analogue was then given, and the plasma-like solution was infused into the intestine for a further equilibration and test period. Blood pressure and pulse rate were taken every 20 minutes throughout the study. Blood samples for VIP and glucose concentrations were taken at the beginning, middle and end of each intestinal sampling period.

\section{ASSAYS}

The intestinal samples from the two aspiration ports were assayed for $\mathrm{Na}^{+}$and $\mathrm{K}^{+}$concentration by flame photometry (Corning, Essex, No. 435), for $\mathrm{Cl}^{-}$ concentration by coulometry (Chloridometer No. 4-2500, Buchler Instr, New Jersey) and for PEG concentration by a turbidimetric method. ${ }^{2}$ Transport of fluid and electrolytes was determined by standard non-absorbable marker equations. ${ }^{3}$

Blood glucose concentrations were assayed using a glucose analyser (Analox GM6 Alpha Laboratories, Hampshire). Plasma VIP concentrations were measured by Professor Stephen Bloom at the Hammersmith Hospital, London.

\section{Results}

LIDAMIDINE STUDY

Absorption of fluid and electrolytes in the jejunum was very low during the control period before administration of lidamidine $(35.4 \mathrm{ml} / 25 \mathrm{~cm} / \mathrm{h}$; normal range $15-280 \mathrm{ml} / 30 \mathrm{~cm} / \mathrm{h}^{4}$ ) (Table 1$)$, and

Table 1 Effect of a $10 \mathrm{mg}$ oral dose of Lidamidine on the jejunal fluid and electrolyte transport of a patient with a VIPoma

\begin{tabular}{lcc}
\hline & Basal & $\begin{array}{l}\text { After } \\
\text { Lidamidine }\end{array}$ \\
\hline Endogenous flow (ml/h) & 48 & $32 \cdot 4$ \\
Net fluid transport $(\mathrm{ml} / 25 \mathrm{~cm} / \mathrm{h})$ & $35 \cdot 4$ & $7 \cdot 8$ \\
Electrolyte transport $(\mathrm{mmol} / 25 \mathrm{~cm} / \mathrm{h})$ & & \\
$\mathrm{Na}^{+}$ & $3 \cdot 8$ & $-0 \cdot 5$ \\
$\mathrm{~K}^{+}$ & $0 \cdot 4$ & $0 \cdot 3$ \\
$\mathrm{Cl}^{-}$ & $2 \cdot 1$ & 3 \\
Mean pulse rate/min & 64 & 66 \\
Mean blood pressure (mmHg) & $119 / 79$ & $118 / 79$ \\
\hline
\end{tabular}

A negative sign indicates secretion 
became lower after the administration of lidamidine. The blood pressure and pulse rate were unaffected by the lidamidine.

\section{SOMATOSTATIN STUDY}

Jejunal perfusion

During the control period, the patient had an abnormally large volume of endogenous fluid $\left(110 \mathrm{ml} / \mathrm{h}\right.$; upper limit of normal $=60 \mathrm{ml} / \mathrm{h}^{4}$ coming into the test segment from above, and a very low absorption of fluid in the test segment $\left(4 \mathrm{ml} / 25 \mathrm{~cm} / \mathrm{h}\right.$; normal range $=15-280 \mathrm{ml} / 30 \mathrm{~cm} / \mathrm{h} .{ }^{4}$ After administration of somatostatin analogue, the endogenous fluid secretion was abolished and the absorption in the test segment was increased to $74 \mathrm{ml} / \mathrm{h}$ (Table 2). Administration of the somatotatin analogue also increased absorption of electrolytes (Table 2).

\section{Ileal perfusion}

The patient had an extremely rapid flow of endogenous fluid entering the test segment from above $\left(488 \mathrm{ml} / \mathrm{h}\right.$; upper limit of normal $\left.=40 \mathrm{ml} / \mathrm{h}^{4}\right)$ and an abnormally low rate of absorption in the test segment $(24.5 \mathrm{ml} / 25 \mathrm{~cm} / \mathrm{h}$; normal range $=25-110 \mathrm{ml}$ $30 \mathrm{~cm} / \mathrm{h}$ ). The endogenous flow was reduced to $284 \mathrm{ml} / \mathrm{h}$ and fluid and electrolyte absorption in the test segment increased after the administration of the somatostatin analogue (Table 2).

\section{Plasma VIP concentrations}

In both the jejunal and ileal studies, the initial plasma VIP concentrations were very high (mean values 157 and $168 \mathrm{pmol} / \mathrm{l}$ respectively; normal

Table 2 Cardiovascular indices and fluid and electrolyte transport in a $25 \mathrm{~cm}$ segment of the jejunum and a $25 \mathrm{~cm}$ of the ileum of a patient with a VIPoma before and after $50 \mu \mathrm{g}$ somatostatin analogue SMS 201-995 (SC)

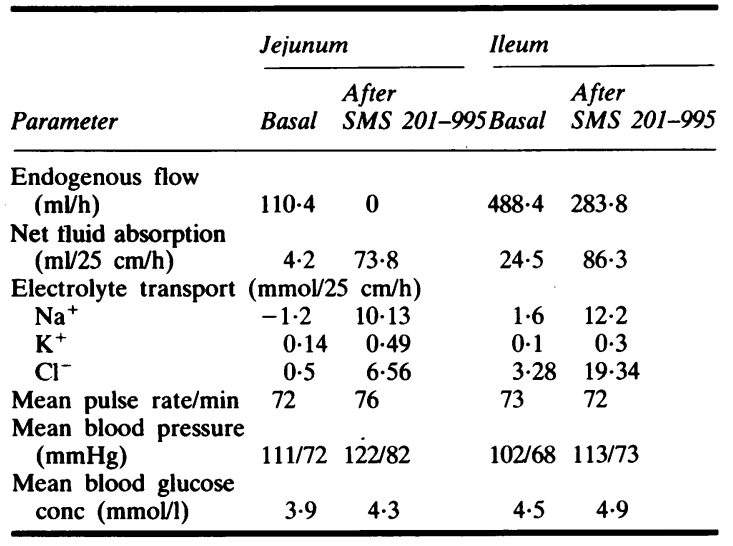

A negative sign indicates secretion. values are $<30 \mathrm{pmol} / \mathrm{l}$ ), but fell to 108 and $125 \mathrm{pmol} / \mathrm{l} 20$ and 40 minutes after administration of the somatostatin analogue and had reached 94 and $99 \mathrm{pmol} / \mathrm{l}$ by the end of each study (125 and 110 minutes after the injection).

\section{Blood pressure, pulse rate}

The blood pressure and pulse rate remained at steady levels throughout both studies (Table 2) and were unaffected by the somatostatin analogue.

\section{Blood glucose}

Blood glucose concentrations did not change when the somatostatin analogue injection was given (Table 2).

\section{Discussion}

The observation that the patient passed between 1 and 3 litres of fluid from the rectum per day even while he was taking nil by mouth, suggests abnormal amounts of secretion into the gut. Because VIP is known to cause copious secretion from the human small intestine and the patient's plasma VIP was raised, we anticipated the perfusion studies would show intestinal secretion. In the event, however, fluid and electrolytes were being absorbed from both the jejunum and ileum, though the rates of absorption were either towards or just below the bottom end of the normal range. Thus it is not possible to explain the patient's diarrhoea on the basis of small intestinal secretion unless either the secretion is coming from a part of the small intestine not sampled by the perfusion technique, or the transport of fluid and electrolytes was shifted in the direction of absorption while the patient was rested undergoing perfusion studies. In support of the latter, many studies have noted that the transport of fluid and electrolytes from the small intestine can vary quite widely between normal subjects and even in the same subjects on different occasions. ${ }^{5}$

Another possibility, however, is that the secretion responsible for diarrhoea is coming from another site in the gut. Vasoactive intestinal polypeptide is a patent pancreatic secretagogue and abnormal secretion from the pancreas could account for, or at least contribute to, the high endogenous flows observed in two out of the three perfusion studies.

Pancreatic hypersecretion is not a well recognised cause of diarrhoea because the normal small intestine has the capacity to absorb well in excess of the maximum amount of fluid the pancreas could secrete. In the situation where intestinal absorption rates are also considerably reduced, however, the large amounts of fluid secreted from the pancreas would remain in the intestinal lumen and result in diarrhoea. The other possibility that the secretion 
was coming from the colon seems unlikely as VIP has not been shown to cause colonic secretion although it can certainly reduce colonic absorption.

Oral administration of the alpha $_{2}$ adrenoreceptor agonist, lidamidine, had no effect on fluid and electrolyte transport in the jejunum or on stool output. This result is surprising in view of the evidence that the drug can inhibit intestinal secretion stimulated by castor oil and cholera toxin in rats, by prostaglandin $E_{2}$ and carbachol in mice ${ }^{6}$ and by deoxycholic acid in dogs. ${ }^{7}$ Also recent studies in normal volunteers showed that oral lidamidine did not affect jejunal fluid and electrolyte absorption but reduced intestinal fluid secretion induced by prostaglandins. ${ }^{8}$ It is unlikely that human tissues are less sensitive to the drug because lidamidine altered short circuit current and sodium and chloride fluxes in sheets of human jejunum and colon ${ }^{9}$ at doses similar to those effective on sheets of rabbit ileum. ${ }^{10}$ It is possible that the oral dose of the drug was flushed away from its site of absorption by the secreted fluid, but we could not test this hypothesis because an intravenous preparation of lidamidine is unavailable. A higher dose of the drug may have been more effective, but the drug was given in the highest recommended oral dosage and acute doses of $20 \mathrm{mg}$ may cause significant reductions in blood pressure (Read and Edwards, unpublished observations), and would be disadvantageous in patients with secretory diarrhoea who may already be hypotensive.

In contrast with lidamidine, the somatostatin analogue increased intestinal absorption of fluid and electrolytes in both the jejunum and the ileum. Experiments in animals have shown that somatostatin (i) can stimulate basal electrolyte absorption in the ileum of the rat, ${ }^{11}$ (ii) can inhibit fluid secretion induced by prostaglandin $\mathrm{E}_{1}$ and theophylline in the rat jejunum ${ }^{12}$ and (iii) can inhibit the pancreatic output of water, bicarbonate and enzymes in dogs stimulated by exogenous secretin as well as physiological stimuli. ${ }^{13}$ It is not possible from our data to decide whether this effect is related to a direct action of the drug on intestinal (and pancreatic) fluid and electrolyte transport or whether it occurred secondary to a reduction in the release of VIP and other peptides, which were not measured, such as peptide histidine isoleucine ${ }^{14}$ from the tumour mass, or whether it interfered with the actions of these peptides on the intestine or the pancreas. Plasma VIP concentrations certainly fell after SMS 201-995 though the lowest value obtained was still three times the upper normal value. In previous studies SMS 201-995 lowered stool output, reduced plasma VIP ${ }^{15}{ }^{16}$ and even reduced the size of the tumour in a patient with a VIPoma. ${ }^{16}$
Somatostatin has also reduced diarrhoea in patients with malignant carciniod syndrome and coeliac disease, ${ }^{17}$ and has decreased fluid and electrolyte losses in patients with ileostomy diarrhoea, ${ }^{18}$ but it had no effect on the stool output of patients with cholera $^{19}$ and did not alter jejunal absorption in normal subjects. ${ }^{20}$

The use of somatostatin itself in the treatment of secretory diarrhoea is limited by the very short half life. SMS 201-995 has a much longer half-life and can be administered by subcutaneous injection. Our patient was able to inject himself with the SMS 201-995 and this allowed him to spend some time out of hospital and to discontinue the oral and intravenous rehydration measures. Our study confirms that SMS 201-995 is useful in the short term management of patients with secretory diarrhoea caused by endocrine tumours.

The authors acknowledge the diagnostic assistance of Dr D R Triger and Prof S R Bloom and are grateful to Prof $\mathrm{R}$ Clark for permission to report this case and Prof L Blumgart for carrying out the surgery.

\section{References}

1 Ruskone A, Rene E, Chayvialle JA, et al. Effect of somatostatin on diarrhoea and on small intestinal water and electrolyte transport in a patient with pancreatic cholera. Dig Dis Sci 1982; 27: 459-66.

2 Malawer SJ, Powell DW. An improved turbidimetric analysis of polyethylene glycol utilising an emulsifier. Gastroenterology 1967; 53: 250-6.

3 Modigliani R, Rambaud JC, Bernier JJ. The method of intraluminal perfusion of the human small intestine. Digstion 1973; 9: 176-92.

4 Read NW, Read MG, Krejs GJ, Hendler RS, Davis G, Fordtran JS. A report of five patients with largevolume secretory diarrhoea but no evidence of endocrine tumor or laxative abuse. Dig Dis Sci 1982; 27: 193-201.

5 Krejs GJ, Fordtran JS. Physiology and pathophysiology of ion and water movement in the human intestine. In: Sleisenger MH, Fordtran JS, eds. Gastrointestinal diseases. 2nd ed. Philadelphia: Saunders, 1978: 306.

6 Mir GN, Alioto RL, Sperow JW, Eash JR, Krebs JB, Yelnosky $\mathrm{J}$. In vivo antimotility and antidiarrhoeal activity of lidamidine hydrochloride (WHR-1142A), a novel antidiarrhoeal agent. Arzneim Forsch 1978; 28: 1448-54.

7 Gullikson GW, Dajani EZ, Bianchi RG. Inhibition of intestinal secretion in the dog. A new approach for the management of diarrhoeal states. J Pharmacol Exp Ther 1981; 219: 591-7. 
8 Edwards CA, Read NW. The effect of lidamidine, a proposed alpha $a_{2}$ adreno-receptor agonist, on salt and water transport in the human jejunum. Dig Dis Sci (In press).

9 McArthur KE, Anderson DS, Durbin TE, Orloff MJ and Dharmsathaphorn $\mathrm{K}$. Clonidine and lidamidine to inhibit watery diarrhoea in a patient with lung cancer. Ann Intern Med 1982; 96: 323-5.

10 Durbin T, Rosenthal L, McArthur K, Anderson D and Dharmsathaphorn K. Clonidine and lidamidine (WHR-1142) stimulate sodium and chloride absorption in the rabbit intestine. Gastroenterology 1982; 82: 1352-8.

11 Dharmsathaphorn K, Binder HJ, Dobbins JW. Somatostatin stimulates sodium and chloride absorption in the rabbit ileum. Gastroenterology 1980; 78: 1559-65.

12 Dharmsathaphorn K, Sherwin RS, Dobbins JW. Somatostatin inhibits fluid secretion in the rat jejunum. Gastroenterology 1980; 78: 1554-8.

13 Kayesseh L, Gyr K, Stalder GA, Rittman WW, Girard J. Effect of somatostatin on exocrine pancreatic secretion stimulated by pancreozymin-secretin or by a test meal in the dog. Horm Res 1978; 9: 176-84.

14 Bloom SR, Christophides ND, Delamarter J, Buell G, Kawashima E, Polak JM. Diarrhoea in VIPoma patients associated with cosecretion of a second active peptide (peptide histidine isoleucine) explained by a single coding gene. Lancet 1983; 2: 1163-5.

15 Maton PN, O’Dorisio TM, Howe BA, et al. Effect of long acting somatostatin analogue (SMS 201-995) in a patient with pancreatic cholera. N Engl J Med 1985; 312: 17-21.

16 Kraenzlin ME, Ch'ng JLC, Wood SM, Carr DH, Bloom SR. Long-term treatment of a VIPoma with somatostatin analogue resulting in remission of symptoms and possible shrinkage of metastases. Gastroenterology 1985; 88: 185-7.

17 Krejs GJ. Peptidergic control of intestinal secretion studies in man. In: Bloom SR, Polak JM, eds. Gut hormones 2nd ed. Edinburgh: Churchill Livingstone, 1981: 516-20.

18 Williams NS, Copper JC, Axon ATR, King RFGJ, Barker M. Use of a long acting somatostatin analogue in controlling life threatening ileostomy diarrhoea. $\mathrm{Br}$ Med J 1984; 289: 1027-8.

19 Molla MA, Gyr K, Bardhan PK and Molla A. Effect of intravenous somatostatin on stool output in diarrhoea due to Vibrio cholerae. Gastroenterology 1984; 87: 845-7.

20 Krejs GJ, Browne R, Raskin P. Effect of intravenous somatostatin on jejunal absorption of glucose, amino acids, water and electrolytes. Gastroenterology 1980; 78: $26-31$. 